\title{
Struggling between Ancient and Modern Life: Yank's Quest of Self-identity in The Hairy Ape
}

\author{
Chen Dang \\ Foreign Studies College, Hunan Normal University, China
}

\begin{abstract}
The Hairy Ape is a canonical masterpiece of the twentieth-century playwright and Nobel Laureate in Literature Eugene O'Neill. Under the social backdrop of dehumanized American capitalism, this play has become one of the most potent plays of realism, expressionism and symbolism in American literature. Since its first rendition, this play has been a subject of numerous literary discussions. This play, revolving around the protagonist Yank's quest for a sense of belonging in a world controlled by the rich, presents a forceful literary analysis of the psychology and identity of an alienated being, and of the impact of industrialization upon human nature. This paper, applying Rousseau's theories of language and education, and Michel Foucault's theories of identity, attempts to deconstructs the concept of being "modern" in the Enlightenment Period, discusses Yank's quest of self-identity in a so-called modern society, who seemingly transforms from a noble savage into a monster and becomes a prey to social values, and demonstrates that personal tragedy results from his failure to come to terms with his identity.
\end{abstract}

Index Terms-The Hairy Ape; Rousseau; Foucault; modern; quest of self-identity

\section{INTRODUCTION}

Eugene O'Neill, the famous American dramatist, who is regarded as the founder of American drama, wins the Pulitzer Prize of Drama for four times in his lifetime and wins the Nobel Prize in Literature in 1936. Just as American master of performance Stella Adler once pointed out: "Unless we look back at the beginning of the American drama led by O'Neill, it is impossible to perform on the American stage." As the only dramatist in American history who has won the Nobel Prize in Literature, O'Neill has spent his whole life exploring the meaning of human existence and he feels in his life potential powers-destiny, God, the old himself, whatever it may be, all of which are mysterious forces ( Liao, 2000, p. 1).

As a sensitive and responsible artist, O'Neill is acutely aware of the eternal tragedy of mankind in life struggles, so he focuses on the value of the tragedy and the force of it. The tragic color of human fate is vividly portrayed by O'Neill's own theatrical characters, which have a legacy of ancient Greek tragedies, and even reach some degree of transcendence, because they are more modern, and keep on the exploration and revelation of the continuity and depth of human dilemmas.

The stoker Yank in the The Hairy Ape can be said to be one of the best examples. He is originally a carefree person, often shoveling coal and humming the song. He even feels that he is a powerful kind, for it is he who makes the ship go forward. However, his destiny plays a trick on him. His dirty appearance happens to be seen by a wealthy lady who accidentally breaks into the bottom cabin of the ship and is stunned to see a "filthy beast" (O'Neill III, 1979, p. 120). The young lady's brief comments awaken him from his unconsciousness as a way to begin his journey to find himself in agony. He can not find his place in all the activities he tries, but it is also difficult for him to return to his prior position. He is so miserable that he goes to the zoo, and attempts to find his companion with a gorilla, but ending with being hugged to death unexpectedly. This highly exaggerated depiction shows the plight of human beings in the quest for themselves, and the inevitable pain and embarrassment when human beings attempt to explore their own identities in a world to which they do not belong at all.

In the twentieth century, with the rise of the idea "the death of God," and the development of science and psychology, the critical reception of the play has undergone drastic changes. At abroad, discussions of The Hairy Ape are mainly about its technical studies - expressionism, dramatic technique so on and so forth; motif or thematic studies - quest for self-identity, alienation so on and so forth; Marxist studies, especially class struggles; tragedy studies-tragic elements, traditional of tragedy so on and so forth; racial and gender studies-masculinity, racial discrimination so on and so forth; and social and cultural studies. It seems that the inclination of the mainstream studies of this play has been increasingly social and cultural. However, regardless of all the similarities to abroad studies of this play, studies at home, though increasing in quantity, gets down to more lopsided and limited vision, such as character analysis, psychological analysis, and tragedy of individuals, with less emphasis on identity crisis and quest for self-identity with relation to culture and society. In light of this, in order to deconstruct the concept of being "modern" in a more inclusive and comparative construction, this paper commits itself to the task of exploring the quest of the self-identity of the protagonist by making use of the theories of Jean Jacque Rousseau and Michel Foucault to update people's 
interpretation of what "modern" really means both in the social background of Enlightenment Period and the contemporary modern age.

The Hairy Ape is a play having much concern about human identities. It discusses the identity of a socialized noble savage who has innate natural simplicity and virtue uncorrupted by American capitalism, and his desperate struggle to participate in the chain of existence. His deformed and ugly side is not an outward expression of his inner quality but a thrust upon him by the mainstream society. With the fast development of industrialization and civilization in the early period of this new century, study of this play, especially its protagonist's quest for identity, has extremely practical significance under the social background of today's cultural and social diversities.

\section{A NAMELESS NOBLE SAVAGE}

This part attempts to carry out a Rousseauian treatment of Yank's early life by discussing his resemblance to a noble savage and the formative influence of education. In his books, Rousseau asserts that man is born good and benevolent, and thinks that social and educational influences are detrimental, for they excite amour-propre which is a kind of harmful emotion, and causes man to be alienated from his authentic self. In this sense, Yank seems like a noble savage without a name due to the mainstream ignorance of his contemporary society. "Yank" can only serve as a code word lacking in substantial meaning and function.

\section{A. A Noble Savage's Self-recognition}

Yank is a man of nature. The physical constitution of him far exceeds that of an ordinary man. Despite his grotesque appearance similar to all his fellow workers, his body has an absolute physical superiority over them: "He seems broader, fiercer, more truculent, more powerful, more sure of himself than the rest" (O'Neill I, 1979, p. 105). Therefore, he has an innate confidence and sense of belonging of himself with regards to his strength and power, which help him to "make a bluff at talkin'—and tinkin'—a'most git away with it—a'most” (O'NeillVIII, 1979, p. 141)! Yank has a strong sense of subjectivity and belonging at first, he does not become bored and slack caused by his monotonous work because of industrial civilization. On the contrary, he regards ship as his home and as part of his life. Just like what Rousseau quotes from Poetics in the beginning of his A Discourse on Inequality: "We should consider what is natural not in things depraved but in those which are rightly ordered according to nature"(Rousseau, 1985, p. 66). To some extent, Yank is a man who is committed to his work and work diligently and responsibly: "One-two-tree- Dat's de stuff! Let her have it! All togedder now! Sling it into her! Let her ride! Shoot de piece now! Call de toin on her! Drive her into it! Feel her move! Watch her smoke! Speed, dat's her middle name! Give her coal, youse guys! Coal, dat's her booze! Drink it up, baby! Let's see yuh sprint! Dig in and gain a lap! Dere she go-o-es” (O’Neill III, 1979, p. 118).

In the limited compartment of this ship, Yank is advantageous in his masculinity so he self-recognizes that he enjoys a certain degree of authority and dominion in the whole stokehole work.

He has a special admiration for the power that propels the ship forward, and he has always regarded himself as the driving force behind the ship, so even though the stokehole compartment is like a hell, Yank loves it enthusiastically. In his heart, it is he that makes the whole world turn. This ubiquitous and omnipotent force makes him feel that he exists and he is proud of his existence. Yank does not take his superiors into consideration: "Say! What's dem slobs in de foist cabin got to do wit us? We're better men dan dey are, ain't we? Sure! One of us guys could clean up de whole mob wit one mit. Put one of 'em down here for one watch in de stokehole, what'd happen? Dey'd carry him off on a stretcher. Dem boids don't amount to nothin'. Dey're just baggage. Who makes dis old tub run? Ain't it us guys? Well den, we belong, don't we? We belong and dey don't. Dat's all' (O’Neill I , 1979, p. 109).

Apart from what has been mentioned above, he is unsophisticated and fallible to fall for "the windy oratory of Senator Queen, glorifying the status quo and denouncing with ignorant terror an threat to it like the I. W. W" ( Zhu, 2004, p. 815). He even releases the gorilla from his cage and approaches it to introduce himself as if they were friends.

Because of his self-recognition, inner pride, reconciliation with his inner self, and his simple nature of justice, Yank takes his position in the whole society seriously. Therefore, later, the contrast between his prior self under his own paradigm and his quest of another self when he is attacked by the new recognition from others foreshadows his destructive ending. He is to some extent a noble savage living in a self-imagining world which is seemingly ancient and less-civilized.

\section{B. A Noble Savage's Education}

Education has played a significant role in people's life. As Rousseau affirms in his book Emile, through education, “imbalances created by man's acquisition" could be avoided, and man's potential can be fully actualized (Rousseau, 1979, p. 3), and education provides "everything which we do not have at our birth and which we need when we are grown" (Rousseau, 1979, p. 38). According to his assertion, the discrepancies between amour-proper and amour de soi is self-evident - amour-proper is the root of man's unpleasant mind, while amour de soi originates from such natural instincts as self-love and self-preservation.

As for Yank, he is man from the stokehole of the ship. All his living circumstances are dim room and dirty and noisy working conditions. He is exposed to this kind of "nature" without a clear glimpse of what the outside world is like. His fellow workers and work itself are all his agents to touch upon his own education and he is accustomed to them all. 
There is no consciousness of the power of education and language despite his own colloquialisms.

As Rousseau writes in Essays on the Origin of Language, "Speech distinguishes man from animal. Language distinguishes nations from each other" (Rousseau, 1997, p. 289). Speech is man's creation and only man can master this tool. As for Yank, though "Tinkin'is hard" (O'Neill VIII, 1979, p. 140), and "It beats it when you try to tink it or talk it - it's way down - deep — behind" (O’Neill VIII, 1979, p. 140), he may want to "tryin' to t'ink” (O’Neill I , 1979, p. 108) and elucidate something out of his mind and take revenge but only leaving in speechlessness, struggle and pain with the occurrence of four-time postures of Rodin's "The Thinker" in the play since his first encounter with Mildred, due to his lack of power in speech. When the secretary in the local I.W.W. office asks about his name, he says: "Name? Lemme tink" (O’Neill VII, 1979, p. 136). He turns out to be a noble savage even without a name for lack of language and social context. That's why the secretary responds sharply by replying: "Don't you know your own name" (O’Neill VIII, 1979, p. 136).

Yank is in some way a kind of noble savage who lives in the ancient time without a name. His society and surroundings have deformed him into a monster who is not only distant from his society but also his authentic self.

\section{A MONSTER'S QUEST FOR SELF-IDENTITY}

This play is a demonstration about the pursuit of sense of belonging and origin. Yank's search for self-identity of his prior self initiating from his encounter of Mildred, who describes him as a "filthy beast" (O'Neill III, 1979, p. 120). According to Foucault, the reasons of Nietzsche's pursuit of origin are "because it is an attempt to capture the exact essence of things, their purest possibilities, and their carefully protected identities; because this search assumes the existence of immobile forms that precede the external world of accident and succession. This search is directed to 'that which was already there,' the images of a primordial truth fully adequate to its nature, and it necessities the removal of every mask to ultimately disclose an original identity" (Albright, 2017, p. 35).

This part attempts to demonstrate the process of Yank's quest for self-identity by dint of Foucault's theories on identity and power theory to illustrate that as for Yank, since his first encounter with the capitalist representative Mildred, he has his moment of awakening and feels confused about who he really is. He is eager to find out the truth and self-prove himself to be the one who he deems is real.

\section{A. The Awakening of Yank}

Since the first encounter with the capitalist representative Mildred, Yank has gone through the turning point of his life. Mildred's words "filthy beast" (O’Neill III, 1979, p. 120) to some extent urge his awakening. Just what Foucault posits in his The History of Sexuality: "Discourses are not once and for all subservient to power or raised up against it, any more than silences are. We must make allowances for the complex and unstable process whereby discourse can be both an instrument and an effect of power, but also a hindrance, a stumbling block, a point of resistance and a starting point for an opposing strategy. Discourse transmits and produces power; it reinforces it, but also undermines it and exposes it, renders it fragile and makes it possible to thwart it" (Foucault, 1978, p. 100-101).

There is a clear-cut contrast of the discourse between Yank's world and the social construction where Mildred belong, which is uncivilized, colloquial, and vulgar while the other is formal, genteel, predominant, and superior, that is to say, the first one is subject to the second. The quest for Yank's identity begins with Mildred's yelling of "filthy Beast" (O’Neill III, 1979, p. 120). Although Yank has been content with his own identity, he is badly hit by the entry of the other class which is represented by Mildred. Mildred is the daughter of a steel company chairman, and her appearance breaks the enclosed environment of Yank's original life, making Yank's self-image a dirty beast in the mouth of others. Yank's pride begins to be disintegrated and insulted. Mildred's occurrence changes Yank's original social relations, his self-positioning and the differences between other people's positioning of him and his own, which cause him to face up with his self-identity and reconsider the question of "who I am".

Therefore, if Mildred is the external factor which forces Yank to find his own identity, then it is his initiative to decide to leave the cruise ship, to regain his dignity and value, and to explore another beginning of his life.

\section{B. Self-proving of Yank}

For Yank, the value and dignity of self-existence can be established again only through a process of self-verification. As a result, he embarks on a tough journey of self-proving. First, he walks out of the shady ship's bunker and follows his companion Long to take a look at the environment in which Mildred lives. This step is of great significance to Yank, which means that he breaks through the small space of self-containment and consciously tries to understand the whole world. In the neighborhood of the wealthy in "Fifth Avenue" of New York City, Yank provocatively went up to gentlemen and ladies to show his own strength and to repair his self-esteem which Mildred has bruised. However, he ends up with disregard and avoidance: "I beg your pardon (He has not looked at YANK and passes on without a glance, leaving him bewildered.)" (O’Neill V , 1979, p. 128-129), leaving his struggle with futility.

Later, following the guidelines of his prison inmates, he goes to the I.W.W. to find his self-reliance and sense of belonging, hoping to embody the power and value of himself through violent revolt, but he is thrown into the street as spies. Finally, he comes to the zoo and releases the gorilla in the cage, thinking that they are both members of "de same club-de Hairy Apes.'(O’Neill VIII, 1979, p. 140) and wanting to push the destruction of the world of steel casting. 
Unexpectedly, he finishes his life by a gorilla's hug, dying in its cage lonely.

As a matter of fact, Yank's awakening and self-improving is a kind of confrontation with and resistance of the marginalized and deserted of his society against the capitalist society without self-consciousness, just like what Foucault assumes: "Foucault's research on issues like madness, prisons, sex, body, punishment, truth, and knowledge is not just single study focused on single problem, but to reveal the essence of modem disciplinary society through deep research on these seemingly marginal issues...It is through the study of these marginal fields and marginal issues that Foucault exposes the sinister, embarrassing and cruel nature of the ruling class in modem disciplinary society" ( Hou, 2018, p. 9).

Discourse can be a means of oppression while it is also a means of resistance. From Yank's deprivation of self to his quest of his another self, during the process of which, according to Foucault, the quest for "truth" and the way power operates are influenced by ratification of authoritative people, consequently the inappropriate discourse cause him to be a social outcast and the marginalized. Regardless of this, his posture of Rodin's "The Thinker" is in some way a representation of his resistance and self-willingness to self-prove himself.

\section{THE FALL OF THE DANGLING MAN}

In the progression of human being's manual work, people struggle out from their original identities, hoping to become the master of the world and the nature but at the same time they are increasingly becoming the slaves of the world they create, and the question of "Where do people come from, and where do we go" is like a never-changing confusion. In some way, human beings are a mixture both of animal-like characteristics and human beings themselves. This holds true for Yank, who has struggled between binary oppositions - "ancient and modern life" with the efforts to break the enigma of self-identity.

\section{A. Rift of Identity: Between Ancient and Modern Life}

O'Neill draws a line between Yank and his coworkers and the greedy and capitalist modern man, that is to say, between ancient and modern civilization. In doing so, he shows us an image of the ancient man and nature living in harmony: "The room is crowded with men, shouting, cursing, laughing, singing - a confused, inchoate uproar swelling into a sort of unity, a meaning - the bewildered, furious, baffled defiance of a beast in a cage" (O'Neill I, 1979, p. 105). Besides, they have some in common: "The men themselves should resemble those pictures in which the appearance of Neanderthal Man is guessed at. All are hairy-chested, with long arms of tremendous power, and low, receding brows above their small, fierce, resentful eyes. All the civilized white races are represented, but except for the slight differentiation in color of hair, skin, eyes, all these men are alike" (O’Neill I , 1979, p. 105).

They are men who live in the past and feels fitted that way though their word "has a brazen metallic quality as if their throats were phonograph horns" while "it is followed by a chorus of hard, barking laughter" (O'Neill I , 1979, p. 105). Thinking is a hard task for both Yank and the gorilla: "It beats it when you try to tink it or talk it—it's way down —deep-behind-you 'n' me" (O'Neill VIII, 1979, p. 140). Besides, four-time occurrences of Rodin's "The Thinker" for Yank and one-time for "The Hairy Ape" in this play indicate that there are definitely some commonalities between them.

In the world of Yank and his fellow workers, everything operates in accordance with the law of nature, without the intervention of God and outsiders' intrusion. There is no distinction between good and evil, and the only need may be a leader. Yank is ugly and monstrous because he has some of the animal-like characteristics and it is these physical traits that make Mildred look at him as a hairy ape, which leads to the beginning of his tragic life.

However, modern industrial civilization is like a powerful and invisible cage, twisting people's humanity and deteriorating people's vitality. By using these symbolic characters and scenes, O'Neill to some extent criticizes modern industrial civilization for wiping out individuality and destroying human nature, thus causing various ethical problems and ills. In fact, before Mildred breaks into the bunker, Yank is mentally balanced, and at that moment he is living in a modern "primitive Jungle" with him as the ruler of his species, but Miss Mildred's definition of "The Hairy Ape" makes him lose his way and demonstrates his own "animal-like" limitations. Under the scope of Mildred, there is a whole picture of a comedy between ancient and modern life, but as for Yank, deep inside this picture is a total different representation: a representation of his tragic root.

\section{B. Confession: "I'm in de Middle"}

Confession, as it is stated by Foucault in his lectures at Dartmouth college, has been assumed "for a long time either as a condition or redemption for one's sin or an essential item in the condemnation of the guilty. For his salvation, one has to know 'as exactly as possible who he is' and, adding to this, one is required to express it as fully and explicitly as possible to other people" (Foucault, 2016. p. 20).

After several confrontations with the representative of capitalist class Mildred, the secretary, some upper-class gentlemen and ladies, and the policeman, Yank finds out the gorilla is the one to whom he can expose his heart: "On'y yuh're lucky, see? Yuh don't belong wit'em and yuh know it. But me, I belong wit'em - but I don't, see? Dey don't belong wit me, dat's what. Get me? Tinkin' is hard-It's dis way, what I'm drivin' at" (O'NeillVIII, 1979, p. 140-141 ). Although Yanks considers that thinking is a difficult task for him, he still tries to pour his heart out to this hairy 
creature to find one who can really understand his confusion and dilemma. Yank is totally lost in this strange and a different world, so he could not truly find his self-identity and sense of belong. He even envies that big creature for that it has a place to belong and the power to wield while he is not: "Youse can sit and dope dream in de past, green woods, de jungle and de rest of it. Den yuh belong and dey don't. Den yuh kin laugh at'em, see? Yuh're de champ of de woild. But me" (O’NeillVIII, 1979, p. 141). From his own perspective, Yank regards himself as an empty man who "got no past to tink in, nor nothin' dat's comin', on'y what's now" and “dat don't belong" (O'Neill VIII, 1979, p. 141). He is the one who misfits the world and gets stuck in between not like this hairy ape who has its own place in the world: "I'm in de middle tryin' to separate'em, takin' all de woist punches from bot' of 'em. Maybe dat's what dey call hell, huh? But you, yuh're at de bottom. You belong! Sure! Yuh're de on'y one in de woild dat does, yuh lucky stiff! And dat's why dey gotter put yuh in a cage, see" (O’NeillVIII, 1979, p. 141)?

In fact, Yank has been dangling between two different social constructions ever since he steps outside of his own world. He can not go back and find his sense of belonging in the capitalist world either. His confession is his cry for subjectivity. Just like Rousseau, in the opening of his story, claims that he is different and unique: "I'm not made like any that exist. If I am worth no more, at least I am different" (Confession I , 1995, p. 5). Therefore, in this sense, Yank's confession is also in some way a demonstration of his rifting identity and a declaration of his failure to reconstruct himself between the ancient and the modern life.

\section{CONCLUSION}

In the Renaissance period, with people's transition of mindsets from the center of God to the center of man, people's individuality has been raised a lot. And after the Enlightenment Period, with more frequent utilization of science and technology, people begin to feel the benefits of those conveniences which have changed their life completely. The sense of being "modern" is pragmatism-oriented and its concept and promise of a better life are prevalent in social construction. Modern at that time is a very progressive word and there is no denying the fact that some may deny it. However, with the rapid development of science and technology, people gradually realize the damage of them which have been greatly brought to people's life. Meaning of being "modern" is no longer concerned with a promise of a better life and it can only bring catastrophe to the entire universe. That is where alienation from the outside begins just as the demonstration of the whole lifespan of Yank.

The image of Yank's being thrown into the cage is actually a vivid reflection of the social circumstances in the 1920s of America: on the one hand, people have to suffer pressure from the materialistic society; on the other hand, they should also maintain the independence of their spiritual life.

Yank is actually an epitome of all the human beings who struggle between the ancient and and the modern life. The play shows O'Neill's deep thinking on the influence of education and society on one's construction of self. Education and society not only shape one's perception of his self but also alienate one from his authentic self. Like what Rousseau says concerning different kinds of education: if the education of society and man does not conform with the education of nature and one's authentic self, bad consequences result (Rousseau, Emile, 1979, p. 38). Regardless of his attempt to resist, Yank, the man who at first resembles a noble savage has been distorted by the influence of society and education. It disrupts his way of life and leads him towards destruction. In this sense, the orientation and positioning of being "modern" and Rousseau's assertion of the function of a nature-oriented education, which abides by one's innate quality and is not at the mercy of the outside forces deserve our deliberate reconsideration, especially in our present-day society.

\section{REFERENCES}

[1] Albright, Daniel. (2014). Panaesthetics: On the Unity and Diversity of the Arts. New Haven: Yale University Press.

[2] Aristotle. (1997). Poetics. New York: Dover Publications.

[3] Foucault, Michel. (1978). The History of Sexuality, Vol. I : An Introduction. Harmondsworth: Penguin .

[4] Foucault, Michel. (2016). About the Beginning of the Hermeneutics of the Self: Lectures at Dartmouth College. Ed. Henri-Paul Fruchaud and Daniele Lorenzini. Tans. Graham Burchell. Chicago: Chicago UP, .

[5] Hou, Qian. (2018). From the Perspective of Foucault's Power Theory: Quest for Lost Identity of Marginalized Group in the Australian Novel Drylands, Anhui: Anhui University.

[6] Liao, Kedui. (2000). Eugene O’Neill: A Collection of Critical Essays (1999). Ed. Beijing: Beijing Language and Research Press .

[7] Liu, Haiping and Zhu Xuefeng. (2004). British and American Drama: Plays and Criticism. Shanghai: Shanghai Foreign Language Education Press.

[8] O’Neill, Eugene. (1979). Selected Plays of Eugene O'Neill. New York: International Collectors Library.

[9] Rousseau, Jean Jacques. (1995). The Confessions. Trans. Christopher Kelly. Hanover: University Press of New England.

[10] Rousseau, Jean Jacques. (1985). A Discourse on Inequality. Trans. Maurice Cranston. London: Penguin Books.

[11] Rousseau, Jean Jacques. (1979). Emile: or On Education, Trans. Allan Bloom. New York: Basic books.

[12] Rousseau, Jean Jacques. (1997). Essays on the Origin of Language, The Discourse and Other Early Political Writings. Cambridge: Cambridge University Press. 
Chen Dang was born in Henan, China in 1995. She is now studying in Changsha, China at Hunan Normal University as a postgraduate student. Her major is British and American Literature. 